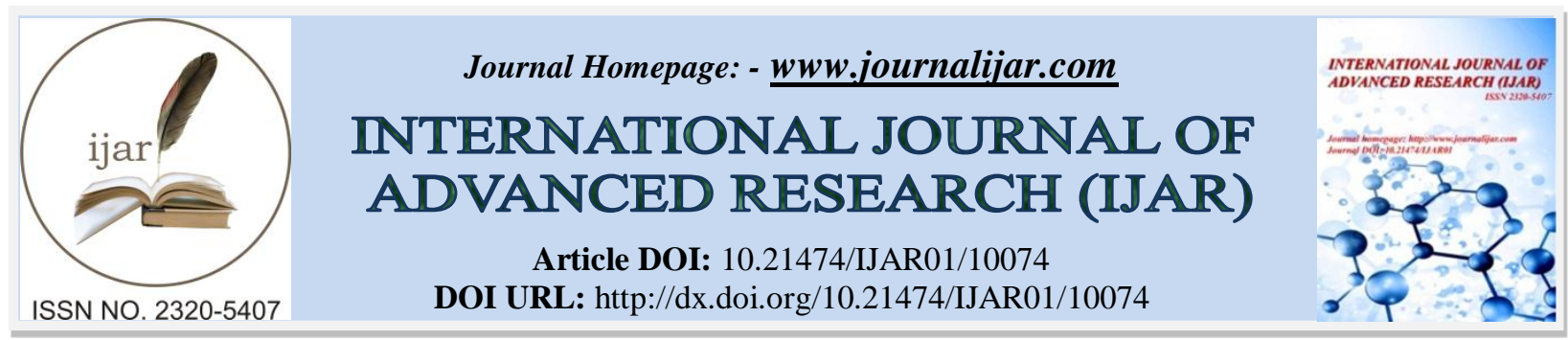

RESEARCH ARTICLE

\title{
COMPARATIVE STUDY OF PULMONARY FUNCTION TESTS IN SEDENTARY INDIVIDUALS AND DYNAMIC EXERCISING PEOPLE.
}

\section{Dr. M. Sreenivasulu ${ }^{1}$ and Dr. S.Amreenisa Begum ${ }^{2}$.}

1. Assistant professor of Physiology, Kurnool Medical College, Kurnool.

2. Professor \& HOD of Physiology, Kurnool Medical College, Kurnool.

\section{Manuscript Info}

\section{Manuscript History}

Received: 12 September 2019

Final Accepted: 14 October 2019

Published: November 2019

Key words:-

Pulmonary Function, Exercise, Sedentary, Athlete.

\section{Abstract}

Background: In the assessment of the respiratory system, pulmonary function tests (PFTs) have achieved a lot of importance nowadays due to an increase in the cardiorespiratory disease and to a steep rise in air pollution. These functional tests and their parameters tend to have a relationship with lifestyle such as regular exercise and non-exercise. Hence, the present study was undertaken to assess the effects of dynamic exercising people exercise in on the respiratory system which are compared with normal healthy sedentary individuals.

Aim and Objective :To study the changes brought about in the respiratory physiology in response to exercise and also to note the changes that do occur as the age advances both in sedentary and exercising individuals

Materials and Methods: PFTs such as forced expiratory volume in $1 \mathrm{~s}$ (FEV1), forced vital capacity (FVC), peak expiratory flow (PEF), VC, and maximum voluntary ventilation (MVV) of the study group were included in the study. The results were analyzed with standard spirometer. The arithmetic means and standard deviations of data have been obtained in the statistical evaluation. As a result of the findings obtained, independent sample t-test has been applied

Results and Conclusion:The results showed significantly increased $(\mathrm{p}<0.001)$ mean FVC, mean FEV1, mean FEV\% and mean PEF in male atheletes practicing regular dynamic exercise and more so in young persons. This suggests that regular dynamic exercise has improved lung function .

Copy Right, IJAR, 2019,. All rights reserved.

\section{Introduction:-}

The field of exercise physiology is at the dawn of a new era. Recent advances in microscopic and biological techniques aided by computerized technology are opening up new frontiers in sub cellular architectural function and adaptation to exercise and training. Public's interest, awareness and enthusiasm as well as thirst for knowledge about the role of exercise can play in shaping one's life style is increasing day by day.

Corresponding Author:-Dr.M.Sreenivasulu.

Address:-Assistant professor of Physiology, Kurnool Medical College, Kurnool. 
Jogging and running represent two of the most popular recreational exercise activities. The effectiveness of walking, jogging which are considered as dynamic exercises plays a dominant role in modifying individual's total health in general and in particular the cardiac and respiratory systems.

The world congress on clinical cardiology accepts that twenty five minutes of walking or cycling at least five days a week keeps the heart attacks away as do the pulmonary physicians who admit that dynamic exercise is more advantageous and beneficial to prevent respiratory diseases like chronic bronchitis etc. Most of us lead a wrong life style that make us old before the actual aging process and die earlier before attaining possible full \& useful lifespan. No one lives forever but one should aim at leading a full lifespan and maintain health throughout the life without becoming a burden to the family and to the society. To achieve this best possible method of leading life is to undertake dynamic exercise in a rational manner so that clinically desirable and potentially beneficial physiological changes occur in the body. This makes us to lead a meaningful healthier life. The dynamic exercise produces a positive impact on the physiology of various organ systems which includes even the pulmonary physiology. Pulmonary ventilation is the phenomenon where by the lungs acting as gasexchanging organs provide the required oxygen to the body tissues and this oxygen is made use of by the cells of the body for their metabolic functions. So the health of the body is reflected by the tests involving the pulmonary function. The pulmonary function tests and their measurements form the basis for evaluating the respiratory system. The pulmonary function tests are classified into different groups like

1. Ventilatory function tests

2. Tests of diffusion

3. Tests of ultimate purpose of respiration.

The ventilatory function tests are meant for the assessment of expansion of lung and chest wall. These tests include the measurements of various lung volumes and capacities. Most of the lung volumes and capacities with the exception of residual volume, functional residual capacity and total lung capacity can be measured by spirometry. The spirometry refers to recording of volume changes during various breathing manouveres. Forced vital capacity, forced expiratory volume in $1 \mathrm{sec}$, forced expiratory volume $\%$ and peak expiratory flow $50 \%$ serve as the lung volumes for assessing the pulmonary functions

Exercise is one of the most frequently faced stress by the respiratory system in day to day life. During the exercise the oxygen consumption and carbon dioxide production may go up to 25 times compared with at rest, depending on severity of the exercise. The respiratory system meets this increased metabolic demand so competently that alveolar and arterial PO2 and PCO2 are practically maintained normal even during the most strenuous exercise. This becomes possible by certain of the respiratory responses to exercise and the responses are increase in pulmonary ventilation, increase in $\mathrm{O} 2$ uptake in the lungs and also the changes at the tissues level. The increase in pulmonary ventilation runs linearly with the increase in intensity of exercise because of increase in depth as well as rate of respiration.

The increase in $\mathrm{O} 2$ uptake in the lungs occurs from $250 \mathrm{ml}$ per minute at rest to about $4 \mathrm{~L}$ per minute during exercise depending on severity of exercise. This is made possible by increased pulmonary perfusion, increased alveolar pulmonary capillary PO2 gradient and increased pulmonary diffusing capacity of the respiratory membrane in the lungs. The blood flow to the skeletal muscles also increases from $2-4 \mathrm{ml}$ per minute per $100 \mathrm{gm}$ muscle tissue at rest to about a maximum of 30 folds depending on the severity of exercise. The ultimate goal of all these accommodative changes in respiratory system is to meet the metabolic $\mathrm{O} 2$ demands of the cells of tissues depending on the intensity of exercise.

Using computerized spirometer (Spiro lab) different age groups of subjects with physical activity like dynamic exercise people (land based athletes) and sedentary subjects are inducted into the present study. An attempt is made to study the variations in pulmonary function tests in the above study population.

\section{Spirometry}

Hutchinson, a London Surgeon in 1846 introduced the concept of spirometry. The primary instrument used in the pulmonary function testing is the spirometer. Spirometry is a measure of Forced Expiratory Volume in $1 \mathrm{sec}$, Forced Vital Capacity and ratio of FEV1 / FVC and peak expiratory flow.

1. Forced Vital Capacity (FCV):After the subject has taken inthe deepest possible breath the volume of air, which can be forcibly and maximally exhaled out of the lungs until no more can be expired. 
2. FEV1 Thisis the volume of air which can be forcefully exhaled from the lungs in the first second and it isthe best characterized test of respiratory function.

3. PEFR This PEFR is defined as the maximum flow, which can be sustained for a period of $10 \mathrm{~ms}$ during a forced expiration starting from the total lung capacity.

4. FEF25\%-75\%:-Flow is often measured over the middle half of the FVC (i.e., between $25 \%$ and $75 \%$ of the expired volume). Using computerized spirometer (Spiro lab) different age groups subjects with physical activity like dynamic exercise people and sedentary subjects are inducted into the present study

\section{Material And Methods:-}

The present study was conducted on various age groups of human being subjects ranging from $24-26$ years, $44-$ 66 years and $64-66$ years male who are physically and clinically in good health i.e no of physically disabled and devoid of any pulmonary, cardiovascular, hematological and clinical abnormalities and also their hemoglobin is more than $10 \mathrm{gms} / 100 \mathrm{ml}$ in all the subjects considered for this subject. To avoid the anthropometric variation all the athletes and sedentary individuals are taken from height range of $1.6 \mathrm{mtrs}$. The subjects considered for the study are divided into 3 groups

1. Group IA : Males sedentary from age $24-26$ years

2. Group I B: Male athletes from age $24-26$ years

3. Group II A : Males sedentary from $44-46$ years

4. Group II B : Male athletes from $44-46$ years

5. Group III A : Males sedentary from $64-66$ years

6. Group III B: Male athletes from $64-66$ years

All the subjects are well informed of the experimental protocol and are thus educated to give maximum cooperaction during the study and also their consent was obtained.

The study was conducted in the pulmonary function tests ,Department of physiology,Kurnool medical college Kurnool and different parameters (FVC, FEV1, FEV1/FVC \%, PEF 50\%, RR) of the study are recorded on the computerized Spirometer model P.K. Morgan model no: Spiro TM 232.

The heights and weights of all the subjects were recorded and also the pulse \& blood pressures were recorded. The subjects were asked to come in the post lunch session between 2-4 pm i.e., 2-3 hours after lunch and were also asked to empty their bladder and to sit in front of the computerized spirometer with mouth piece held firmly between the lips and the nose clip is applied, the subject is asked to inhale and exhale into the spirometer and such three readings are taken, out of which the average (mean) is taken as a standard reading for the study. Statistical Analysis :Data are reported as mean and standard deviation (+SD). Means are compared between two groups by (students unpaired) $t$ test.

\section{Analysis Of Results:-}

Showing Comparision Of Mean Pulmonary Function Test Values In Male Sedentary And Athletes Of 24 - 26 Years Age Group

\begin{tabular}{|c|c|c|c|c|c|c|c|c|}
\hline \multirow{2}{*}{ PFT } & \multicolumn{2}{|c|}{ SEDENTARY } & \multicolumn{2}{|c|}{ ATHLETES } & \multirow{2}{*}{$\begin{array}{c}\mathrm{T} \\
\text { Value }\end{array}$} & \multirow{2}{*}{$\begin{array}{c}\mathrm{P} \\
\text { Value }\end{array}$} & \multirow{2}{*}{$\begin{array}{l}\text { Crude } \\
\text { value }\end{array}$} & \multirow{2}{*}{$\begin{array}{l}\% \\
\uparrow \downarrow\end{array}$} \\
\hline & Mean & SD & Mean & SD & & & & \\
\hline FVC & 4.467 & 0.074 & 4.98 & 0.15 & 15.342 & $<0.001$ & 0.10 & $11 \% \uparrow$ \\
\hline FEV1 & 3.585 & 0.051 & 4.077 & 0.115 & 19.563 & $<0.001$ & 0.119 & $13 \% \uparrow$ \\
\hline FEV1\% & 80.4 & 0.68 & 82.48 & 0.441 & 12.832 & $<0.001$ & 3.91 & $2 \% \uparrow$ \\
\hline PEF50\% & 4.104 & 0.0789 & 4.462 & 0.108 & 13.391 & $<0.001$ & 0.472 & $8 \% \uparrow$ \\
\hline
\end{tabular}


Showing Comparision Of Mean Pulmonary Function Test Values In Male Sedentary And Athletes Of 44 - 46 Years Age Group

\begin{tabular}{|c|c|c|c|c|c|c|c|c|}
\hline \multirow{2}{*}{ PFT } & \multicolumn{2}{|c|}{ SEDENTARY } & \multicolumn{2}{|c|}{ ATHLETES } & $\begin{array}{c}\text { T } \\
\text { Value }\end{array}$ & $\begin{array}{c}\text { P } \\
\text { value }\end{array}$ & $\begin{array}{c}\text { Crude } \\
\text { Value }\end{array}$ & $\begin{array}{c}\% \\
\uparrow \downarrow\end{array}$ \\
\cline { 2 - 9 } & Mean & SD & Mean & SD & & & \\
\hline \multirow{2}{*}{ FVC } & 3.98 & 0.04 & 4.15 & 0.09 & 8.634 & $<0.001$ & 0.17 & $4 \% \uparrow$ \\
\hline FEV1 & 2.934 & 0.02 & 3.254 & 0.063 & 24.222 & $<0.001$ & 0.320 & $10 \% \uparrow$ \\
\hline FEV1\% & 73.79 & 0.974 & 78.6 & 2.2 & 9.996 & $<0.001$ & 4.81 & $6 \% \uparrow$ \\
\hline PEF50\% & 3.239 & 0.013 & 3.914 & 0.043 & 1.683 & $<0.001$ & 0.675 & $21 \% \uparrow$ \\
\hline
\end{tabular}

Showing Comparision Of Mean Pulmonary Function Test Values In Male Sedentary And Athletes Of 64 - 66 Years Age Group

\begin{tabular}{|c|c|c|c|c|c|c|c|c|}
\hline \multirow{2}{*}{ PFT } & \multicolumn{2}{|c|}{ SEDENTARY } & \multicolumn{2}{|c|}{ ATHLETES } & \multirow{2}{*}{$\begin{array}{c}\mathrm{T} \\
\text { value }\end{array}$} & \multirow{2}{*}{$\begin{array}{c}\mathrm{P} \\
\text { value }\end{array}$} & \multirow{2}{*}{$\begin{array}{l}\text { Crude } \\
\text { Value }\end{array}$} & \multirow{2}{*}{$\begin{array}{l}\% \\
\uparrow \downarrow\end{array}$} \\
\hline & Mean & SD & Mean & SD & & & & \\
\hline FVC & 2.39 & 2.49 & 0.03 & 0.012 & 16.06 & $<0.001$ & 0.10 & $4 \% \uparrow$ \\
\hline FEV1 & 1.892 & 2.021 & 0.024 & 0.032 & 16.170 & $<0.001$ & 0.119 & $6 \% \uparrow$ \\
\hline FEV $1 \%$ & 74.7 & 78.61 & 1.801 & 0.65 & 10.215 & $<0.001$ & 3.91 & $5 \% \uparrow$ \\
\hline PEF50\% & 2.436 & 2.908 & 0.081 & 0.097 & 18.684 & $<0.001$ & 0.472 & $19 \% \uparrow$ \\
\hline
\end{tabular}

\section{Discussion:-}

The study conducted shows that the individuals who have sedentary lifestyle have lung function values significantly lesser than thedynamic exercising people. The results of study show that there is significant improvement in mean FVC, mean FEV1, mean FEV\% and mean PEF. The results are supported by the study of A K Mehrotra PK, Verma N, Yadav R, Tewari S, Shukla N, Mac Auley D, McCrum E, Evans A Stott G, Boreham C, Trinick T et al who reported significant increase in the above said values. Pulmonary function tests by spirometry permit early identification of abnormalities associated with many respiratory diseases. These tests would also provide valuable information in monitoring disease progression, response to treatment and rating disability due to occupational hazards. These tests are user friendly, non-invasive. As per the study, dynamic exercise can improve lung function and delay in age related changes in respiratory system and thus the respiratory diseases as well as cardiovascular diseases also.

\section{Summary}

The present study is completed by fulfilling the aims and objectives. The study revealed that the parameters chosen to reflect the pulmonary functions were best among dynamic exercising people. The study revealed that the dynamic exercising people's performance was better when compared with sedentary subjects. The present study has thrown some light on the need for pulmonary function tests as a screening method to identify the subjects who may be prone for respiratory disorders. The vast improvement in sophisticated technology helps in solving the problems of diagnosis of pulmonary lesion and the obstructive and restrictive diseases which can be interpreted clinically as well as physiologically. 


\section{References:-}

1. A.K.De. Some physical efficiency tests on Bengalese football goal keepers. British Journal of Sports Medicine. $1979 ; 13 ; 173-175$

2. A. K. Ghosh, A. Ahuja and G. L. Khanna. Pulmonary capacities of different groups of sports men in India. British Journal of Sports Medicine 1985; 19; 232-234.

3. Astrand I. The physiological work capacity of workers 50-64 years old. Acta Physiological Scandinavian Journal. 42:73-86, 1958.

4. Benjamin Burrows, Michael D. Lebowitz, Anthony E. Camilli, and Ronald J. Knudson. Longitudinal changes in forced expiratory volume in one second in adults. American Review of Respiratory Diseases 1986; 133(6):974980.

5. C Kesava Chandran R. Harikuman Nair and S.

6. Shashidhar. Respiratory function in Kalariyapattu practitioners. Indian Journal of Physiology and Pharmacology 2004: 48(2): 235-240

7. Enright PL, Johnson LR. Connett JE, Voelker H, Biust As Spirometery in the lung health study. Methods and quality control Mayo Clinic. Rochester, MN 55905 PMID 2048803[pubmed indexed for Mediline].

8. Ferris BG, Anderson DV, Zickmantel R. Prediction values for screening tests of pulmonary functions. American Review of Respiratory diseases 1965: 91: 252-261.

9. J. A. Neder, S.Andreoni, A. Castelo - Filho and L.E.Nery. Reference values for lung function tests. Static volumes. Brazilian Journal of Medicine Respiration June 1999, Volume 32(6) 703-717.

10. James M Hagberg, John E Yerg II and Douglas R. Seals. Pulmonary function in young and older athletes and untrained men. Journal of Applied Physiology 65(1); 101-105 : 1988.

11. Lakhera S C, Kain T C, Bandopadhyay P. Changes in lung function during adolescence in athletes and nonathletes. Indian Journal of medical sciences. 669-676. Issue 12. Vol-55,2001.

12. M.B. Dikshit, S. Raje and M.J. Agarwal. Lung function with spirometer : An Indian perspective on the vital capacities of Indians. Indian Journal of Physiology and Pharmacology 2005; 49(3); 257-270.

13. M.R.Miller, R.Crapo. J. Hankinson. V.Brusasco. F. Burgos, R.CasaburiA. Coates, P. Enright, C.P. M Van Der Grinten, P.Gusatafs son, R. Jensen, D.C. Johnson, N.Maclntyne, R.McKay,D.Nayajas, O.F.Pederson,R.Pellegrino, G.Viegi and J.Wanger. General consideration for lung function testing. European Respiratory Journal 2005; 26: 153-161.

14. Mason R J, Broaddlus V C, Murray J F, Nadel J A. Murray and Nadel's. Text book of Respiratory Medicine. Pulmonary function tests, 4th Ed. Philadelphia, Pa: Saunders; 2005.

15. Rao MN, Sengupta A, Saha PN Sitadevi A. Physiological norms in Indians. Pulmonary capacitive in health ICMR special report No:3,1961

16. Mehrotra P K, Varma N, Tiwari S, Kumar P. Pulmonary functions in Indian sportsmen playng different sports. Indian Journal of Physiology and Pharmacology issue 1998, july 42(3) pages; 406-412. 